\title{
Oisin's Quest: The Myth of the Modernist Poet's Evolution
}

\author{
Mauricio D. Aguilera \\ Universidad de Granada
}

\begin{abstract}
This article offers an interpretation in terms of metapoetic theory of The Wanderings of Oisin, Yeats's first important work. Our purpose is to prove that an analysis of the poem upon this basis can be useful to solve the semantic problems caused by many of the motifs as well as illuminating for the elucidation of the meaning of Oisin's journey through three mysterious islands. Taking the poem as a symbolic enactment of the poet's notion of his own artistic growth, we argue that each of the islands might correspond to different yet closely related models of poetry. The poem can then be seen as a gradual progression which includes a model of pure or subjective poetry (the Island of Dancing), a model of objective socially committed poetry (the Island of Victories) and finally an ideal of poetic language based upon the onirical experiences as the only legitimate source of knowledge (the Island of Forgetfulness).
\end{abstract}

Since its publication in 1889 , The Wanderings of Oisin has attracted critical attention from different-if not opposing-standpoints. Critics have always pointed out its uncanny symbolic structure and have endeavoured to elicit the symbolic meaning which underlies a great number of the motifs present in the poem. In fact, the symbolism of many of its elements was already recognised by Yeats himself shortly after the publication. In a letter to Katharine Tynan the poet does not hesitate to affirm that "Oisin needs an interpreter" (Letters 111) and even though he had once recommended that the poem should not be interpreted-for this would entail the destruction of its artistic value-the truth is that the work in question has generated a good deal of critical interpretation from every conceivable perspective and the results have not always been entirely successful. Thus, although critics have almost unanimously agreed that symbols are a key element in the structure of Oisin, the interpretative analyses which they have offered for its correct understanding, far from being complementary, have proved to be exclusive, even to the extent of ruling each other out. Perhaps more important is the fact that the analyses provided up to the present draw on the interpretation of isolated episodes in the 
poem-Oisin's never-ending battle with the demon in Book II or the obsessive tree, bird and sea imagery-but never have they attempted to carry out a comprehensive exegesis of the poem as a unified whole.

The aim of this paper is, then, to further complicate the critical controversy by suggesting that The Wanderings of Oisin can be read as a mythical or symbolic enactment of the modernist poet's notion of his own evolution; an evolution which necessarily comprises three different yet related conceptions of the true ideal of poetry: first, poetry as a subjective discourse; secondly, poetry as a object-oriented discourse and finally poetry as a timeless creative process. Before I make these suggestions, however, it will be helpful if I review some aspects of the poem.

\section{I}

The subject-matter of Yeats's first important poetic production is simple: Oisin, the son of Finn, abandons his country after having met Niamh, Aengus's daughter, with whom he falls in love. They begin their long journey on horseback riding across the sea; a journey divided into three stages which coincide with the three islands which they encounter. Thus, Oisin enters the world of the Immortals and gains the gift of eternal youth for three centuries. During all this time, he always feels the pressing need to see his brave people again, even though this may break the spell of his perpetual youth. When he finally returns to the country he has been longing for, he finds that the Ireland he left has dramatically changed: Christianism has substituted the old Pagan civilization. Oisin, now a lean and decrepit man, caught up in the dilemma of either accepting the new world as it is or of dying as a warrior of the Fenian people, opts for the latter alternative. Broadly speaking, this is the plot of the poem, and critics have always pointed out the inevitable passage of Time as its main theme, since this was a major thematic force in Yeats's later poetry. In 1932, the author himself interpreted the poem in the following terms:

I have just finished the first volume, all my lyric poetry, and am greatly astonished at myself. As it is all speech rather than writing, I keep saying what man is this who... says the same thing in so many different ways. My first denunciation of old age I made in "The Wanderings of Usheen" (end of part 1) before I was twenty and the same denunciation comes in the last pages of the book. (Unterecker 47-48)

This has been the critical line followed by Ellmann, Unterecker, Jeffares and others. For Unterecker the main theme of the poem is "the horror of old age that brings wisdom only at the price of bodily decrepitude and death" (47-48). Oisin could be seen as the first attempt to dramatise the disruptive force of Time which reveals both the fragile nature and the brittle identity of the self. Norman Jeffares provides an identical critical interpretation: "Oisin deals with a theme that was to become Yeats's central obsession ... the theme of old age versus perpetual youth, mortality versus immortality, change versus changelessness" (14). As for Ellmann, he sees the poem as "an exemplum of the rise and fall of life" (18). 
Langbaum's approach proves, however, much more interesting in this sense. $\mathrm{He}$ interprets Yeats's work as an attempt to represent the dialectic relation between progress and the advance of Time (epitomised by Saint Patrick) and the values of the past (represented by Oisin). Yeats's early attitude towards this dichotomy would, then, coincide with Oisin's final choice, "to die with the old rather than be reborn with the new" $(147-48)$. The poem might well be interpreted as an utter rejection of the real Ireland anchored to the antiheroic ideal of Christian life and as a regressive escape from history in the quest for a substitute cultural identity. In other words, Oisin might represent the almost extinct ideal of a glorious civilization which refuses to submit to the dominant ethical code of servility and humbleness provided by Christianism: "But now the lying clerics murder song/With barren words and flatteries of the weak" (Poems 22). ${ }^{1}$ Thus, the past heroism of Finn's warriors is constantly contrasted to the antiheroic figure of the saviour acclaimed by Christianity: "And at his cry—says Oisin recalling the bravery of his people - there came no milk pale face/Under a crown of thorns and dark with blood,/But only exultant faces" (20).

Structurally, the poem is divided into three books and each of them corresponds to one of the three clearly distinct stages of Oisin's journey through the dreamland of the Immortals. From the point of view of poetic technique, although the poem takes the form of a dialogue between Saint Patrick and Oisin, the discoursive function of the first is simply that of being an almost mute interlocutor who listens and occasionally rebukes Oisin's "heathen fantasies." In fact, the poem uses one of the most popular genres of the Victorian period: the dramatic monologue. I do not intend to enter here into a discussion on the ideological implications which underlie the use of this poetic device. Suffice it to say that the Victorians used it as a secure means to wipe out any trace of subjective emotion which the readers could identify as indisputably belonging to the poets's private sphere (Langbaum 69-103). The dramatic monologue arises, then, at least originally, as a mask which the poet can put on in order to avoid any possible connection between him and the poetic "persona" of his poems. In this sense, Oisin could be interpreted as the poetic mask which Yeats wears to express a series of personal attitudes towards such a decisive question as the poet's relation to the notion of progress and change in history. This does not mean, of course, that Oisin represents Yeats's alter ego in a strict sense. But if our suggestion is correct, he might well epitomise the figure of the poet, or rather the role which the artist has to accomplish both in relation to the outer world and to his own poetic evolution. Frank Kermode rightly argues that one of the defining features of the modernist poet and artist in general is his self-conscience as an individual cut off from the world and secluded in a poetic reality which cannot be experienced by the rest, since it is not subject to the human laws of time and space. Poetry is therefore the "supernatural" gift or visionary perception with which only a few chosen have been blessed (1-29). But in which way does Oisin incarnate this archetypal image of the poet? First of all, Oisin leaves his world in the quest for an ideal of beauty and immortality which cannot be found within the narrow limits of the world he inhabits. Thus, he is forced to leave his fellow-warriors precisely when the irresistible vision of Niamh has captivated his mind. In doing so, he is bound to leave behind his mortal origin, i.e. his flesh-and-blood nature, and during the long journey through the vast land of poetic imagination he constantly feels nostalgia for the 
world which he has voluntarily abandoned. Following the critical interpretation I have proposed here, we might surmise that Oisin is the epitome of the modernist poet and that Niamh is the symbol of poetry which the artist must follow and to whom he must pay his tribute. Niamh can then be seen as a new reincarnation of the mythical White Goddess that forces the poet to set out on an introspective journey in the quest for an enduring ideal of beauty and a model of poetic inspiration (Graves). This interpretative premise, upon which I shall base my analysis, provides at least two advantages. First, it allows us to give an overall view of the symbolic meaning of the poem as a unified structure. Second, it enables the reader to interpret it as a symbolic enactment of the three phases which the poet has to follow in order to achieve what Yeats called "a vision of reality which satisfies the whole being" (Letters 588). The Wanderings of Oisin can then be read as Yeats's early attempt to give a dramatic form to some of the nodal axes of the poetic theory which he developed at length and fully systematized in his later prose writings.

Apart from the theme of the passage of Time which pervades the structure of the poem from the initial stanza, there has always been an excessive interest in elucidating the meaning of the three islands-Dancing, Victories and Forgetfulness-which Oisin finds on his three-century journey. In fact, the presence of these islands, far from being a secondary issue, has occupied a central position in scholarly criticism. The reason for this inordinate attention is not coincidental at all: the three islands determine to a great extent the very structure of the poem-its division into three books, as already pointed out. Here, however, critical problems begin. Yeats himself gave hints as to the interpretation of the islands. Discussing the difficuties inherent in the poem, he remarked: "There are three incompatible things which man is always seeking: infinite feeling, infinite battle, infinite repose-hence the three islands" (Unterecker 42).

But the truth is that he never clarified what he really meant with the symbolism of the islands. In a letter written in 1888 he complicated things even more by warning that "the whole poem [was] full of symbols" which only he was able to decipher:

In the second part of "Oisin" under disguise of symbolism I have said several things to which I only have the key. The romance is for my readers. They must not even know there is a symbol anywhere. They will not find out. If they did it would spoil the art. (Unterecker 49)

But however hard Yeats tried to disguise his symbols and to discourage critical interpretation of them, the fact is that the list of books and articles written on this issue has been endless. In relation to the motif of the three islands, Ellmann's theory (1954) is perhaps one of the most widely accepted and doubtless the most comprehensive. He first notes that one of "his most drastic modifications" of Comyn's poem made by Yeats was the transformation of the country of the young into three islands, of which the critic gives an interpretation on two levels: 
On the personal level, they represent Yeats's idyllic boyhood at Sligo, his subsequent fights with the English boys in South Kensington because he was Irish, and his daydreaming adolescence on Howth. But these three stages in his life had wider implications, for they paralleled the periods of childhood, of aggressive maturity, and of senility in the lives of all men. (18)

Ellmann's theory, however suggestive and plausible it may seem, suffers from an important mistake. He draws his interpretation on a purely biographical basis: Oisin is simply the literary incarnation of Yeats. Accordingly, the idyllic island of Dancing, the dreadful island of Victories and the tranquil island of Forgetfulness, which the hero finds on his journey, represent the three important cities in which Yeats spent his life: Sligo, London and Howth or Dublin; and they symbolically contain the most important features of man's stages of life: the innocence of youth, the problems and the struggle of maturity and the peacefulness of old age. This is not, however, a very accurate interpretation of their symbolic status and it is to a large extent a simplification of the entire problem, as it leaves too many questions unsolved. His interpretation of the second island as England and the chained lady which Oisin delivers as Ireland is even more daring:

He did not forget to connect the myth with his nation: the chained lady whom Oisin has to liberate in the second island bears a strong resemblance to Ireland in English chains, and Oisin's "battles never done" suggest the never-ending Irish struggle for independence. (18-19)

Ellmann seems to overlook the other symbolic elements which accompany the description of the second island: Oisin for example fights with an ever-changing demon ${ }^{2}$ and the lady whom he rescues is not only enchained but also imprisoned in a tower, which can only be reached through a wide stair. Thus, we have come across three key pieces in Yeats's symbolic system. It is at the very least surprising that critics, obsessed with possible psychoanalytic or biographical sources of the poem, have overlooked such fundamental elements in the analysis of Oisin.

Taking Freudian theories as the basis of interpretation, the conclusions which some critics have drawn are even more surprising. Morton Seide, for instance, interprets the never-ending battle with the demon as an image of Yeats's fight with the authoritative father-figure, but later on he changes his mind and identifies this motif with the cyclical movement of seasons. Last but not least, Oisin's death-fight with the demon has also been interpreted as the poet's repression of sexual desire (Unterecker 47-66). Faced with this myriad of interpretations, each pointing in a different direction, one can but feel puzzled and almost entirely unable to escape from this interpretative impasse. In my opinion, the true reason for this inability to reach a consensus in the elucidation of the symbols which operate in Oisin seems to lie in the tendency to explicate the poem as an isolated unit which bears no relation to Yeats's idea of his own poetic production. This might account for the fact that the poem has never been read as an early attempt of Yeats's at creating a mythical fable of his conception of poetry and of his notion of the poetic evolution which a true poet is bound to undergo. I will, then, try to analyse Oisin's journey and his stay on 
each of the islands as the three inevitable phases which Yeats thought that a genuine artist had to go through. These three stages in the growth of the poet are: (I) The concept of Pure or Subjective Poetry identified with the Island of Dancing; (II) The concept of Social or Objective Poetry enacted in the Island of Victories; and (III) The concept of Timeless or Visionary Poetry represented by the Island of Forgetfulness.

(I) The Concept of Pure or Subjective Poetry or the Island of Dancing

The concept of pure poetry is closely associated with the French symbolist poets and the Symbolist Movement in general. More accurately, the term has been applied to the PostEnlightenment poetic practice based upon the assumption that poetry is a subjective discourse which springs from the private sphere of the self; a discourse which stands in opposition to the historical objective discourse characterized by its attempt to represent the contingent outer world. This ideological division into subjective (lyric) and objective (epic) discourses was already established by Kant, when he split the self's identity into two complementary yet opposing levels: the transcendental level (the atemporal domain of subjective truth) and the empirical level (the pollution of the ever-changing world). And it is precisely this ideological conception of poetry as a transcendental language stemming from the first of these levels that is going to prevail over the nineteenth and twentieth centuries (Montero 17-24).

Turning to the analysis of the poem, it is evident that what Oisin finds in the Island of Dancing is no other than this idyllic vision of poetry as the inaccessible temple of subjectivity. A sanctuary which is far from the hubbub of the real world ("beyond the tumbling of this tide") and in which the human experience of time is completely unknown. Niamh, the reincarnation of the White Goddess, ${ }^{3}$ asks the hero to take her to a symbolic place where:

... men have heaped no burial-mounds, And the days pass by like a wayward tune, Where broken faith has never been known, And the blushes of first love never have flown. (7)

Oisin, "fallen into a desperate gulph of love," accepts her request and they ride "out from the human lands." The first island they visit, carefully depicted throughout the first book of the poem, is in fact a recreation of the Romantic vision of Nature secluded from the social pressures of the civilised world; a first version of Yeats's poetic fairyland whose inhabitants-the Immortals-do not know the meaning of words like Time, Death or Sorrow. Oisin is, of course, an outsider and his flesh-and-blood nature is at once recognised by the "band of men and ladies" of the island:

And when they saw the cloak I wore

Was dim with mire of a mortal shore

They fingered it and gazed on me 
And laughed like murmurs of the sea. (11)

More important perhaps, when Oisin, "the strange human bard," tries to join in their singing he is unable to conceal his mortal origin and fails to keep in tune with the harmony of the island:

But when I sang of human joy

A sorrow wrapped each merry face

And, Patrick! by your beard they wept. (11)

Furthermore, there are two symbolic elements in this island, the importance of which should be stressed from the start. We refer to the bird-imagery and the symbolism of dancing. Birds play a fundamental role in Yeats's poetry, as has often been ascertained. But as far as the depiction of the Island of Dancing is concerned, the presence of birds is so overwhelming that it becomes one of its most important defining features. In fact, it is precisely the countless number of birds that first draws Oisin's attention when he approaches the island:

Round every branch the song-birds flew,

Or clung thereon like swarming bees;

While round the shore a million stood

Like drops of frozen rainbow light . . (10)

Unterecker interprets this ubiquitous presence of birds as a symbol of poetry: "Perhaps because art is phoenix-like, immortal, the 'coloured Asian birds' also populate the first island" (51). The interpretation given by Hazard Adams seems more accurate. Adams recognises the complex symbolic structure of birds in Yeats's poetry and analyses them primarily as symbols of "strange subjectivity" and mystery (250-89). The poet's words are clear enough in this sense:

Certain birds . . a are natural symbols of subjectivity, especially when floating upon the wind alone. Or alighting upon some pool or river, while the beasts that run upon the ground, especially those that run in parks, are the natural symbols of objective man. (Adams 251 emphasis added)

If Adam's interpretation is correct, as it seems to be, this would mean that the Island of Dancing enacts the world of pure subjectivity and perpetual emotion. In a very similar line, Bachelard interprets bird-images in poetry-particularly those found in Shelley's work - as a symbol of the poet's desire to escape from the time-bound reality and his desperate need to embrace some Utopian ideal which cannot be realized in the material world. Birds are, then, emblems of the free spirit which has managed to liberate itself from the law of gravity and thereby enter into the aethereal world of poetic imagination (106-15).

In connection with this bird-symbolism we should see the importance of the ritual of dance on the island. In fact, not only its inhabitants but also the birds and even the trees 
partake of this uncanny and ceaseless dance, which seems to defy both the harmful influence of Time and the threat of the "grey wandering osprey Sorrow": "And in a wild and sudden dance/We mocked at Time and Fate and Chance" (13). Trees tremble "ceaselessly,/As though they all were beating time,/Upon the centre of the sun,/To that low laughing woodland rhyme" (10); birds keep "time with their bright wings and feet" (16) and the Immortals spend their life dancing "like shadows on the mountains" (15). What is at issue here is the symbolism of dancing as the only passionate rhythmic motion which can embody the aesthetic principle of Beauty as a pure form unsoiled by intellectual abstraction. I will not enter into a discussion on the development of the Dancer-motif and its ideological implications throughout the Symbolist Movement. Suffice it to say that the dance soon became one of the clearest images of pure poetry, simply because it could evoke meaning through sensuous visual images and the rhythm of the disembodied musical form. Arthur Symons remarks apropos of the symbolic connotations of dance:

... the intellectual as well as sensuous appeal of a living symbol, which can but reach the brain through the eyes, in the visual, concrete, imaginative way; has seemed to make the ballet concentrate in itself a good deal of the modern ideal in matters of artistic expression. Nothing is stated, there is no intrusion of words used for the irrelevant use of describing ... and the dancer, with her gesture, all pure symbol, evokes, from her mere beautiful motion, idea, sensation, all that one need ever know of event. (Kermode 73-74 emphasis added) ${ }^{4}$

Accordingly, the dance epitomises the form of art par excellence, since it enacts the most perfect unity between the language of gesture and motion (body) and the language of music (soul). For this reason, it is not surprising that in the first of the islands that Oisin finds in his journey, Dancing, as the emblematic form of pure poetry and art for art's sake, plays such a fundamental role.

However, the concept of pure poetry which Symbolism put forward as the only possible form of art soon displayed its contradictory nature: on one hand, it enabled the poet to exile himself to an unreal world of his own, i.e. in a kind of non-existent fairyland. On the other, it only permitted a very reduced poetic space which made it literally impossible for the poet to reconcile himself with the real problems of the outer world. Edmund Wilson analyses this problem of the modernist poet in relation to Yeats's poetic evolution:

In Yeats, we find the aestheticism of Pater carried through to its consequences. What is the consequence of living for beauty, as beauty was then understood, of cultivating the imagination, the enjoyment of aesthetic sensations, as a supreme end in itself? We shall be thrown fatally out of key with reality-we shall incur penalties which are not to be taken lightly. There is a conflict here which cannot be evaded; and Yeats, even in his earliest period, is unceasingly aware of this conflict. (34)

And this is why he is soon forced to give up the subjective image of the fairyland and the aesthetic contemplation of the dancers of the Alchemical Temple. Oisin is also aware 
of this conflict: he finds "a staff of wood" floating on the sea and immediately realizes he has lived far from his people for too long:

I turned it in my hands; the stains

Of war were on it, and I wept,

Remembering how the Fenians stept

Along the blood-bedabbled plains,

Equal to good or grievous chance. (15)

And it is then that he decides to undertake another journey in the quest for a new and more real ideal of poetry.

\section{(II) The Concept of Objective Poetry or the Island of Victories}

Oisin's departure from the innocent Island of Dancing is motivated by the impossibility of that world to remove the oppressive burden of Time in any permanent way. When he finally decides to leave the isle, the Immortals' farewell-song reveals Oisin's fate: he is doomed to return to a world where Time can only bring about gradual decay, destruction and ultimately death. More important perhaps, their song anticipates his transformation into an "old man" who "bends to the fire and shakes with the cold,/While his heart still dreams of battle and love" (16). Yet Oisin is strongly determined to leave that innocent world of endless dancing, partly because his growing feeling of isolation is too painful to be ignored, and partly because he is still confident that he will be able to find a model of poetry which can bring him back to and somehow reconcile him with the real world.

The only unsolved problem is to determine what kind of poetry Yeats seeks in order to bridge the gap between the subjective emotion of his early poems and the objective reality of the outer world. The answer is not always sufficiently clear in Yeats's poetic theory, simply because he considerably complicated his theoretical writings by attempting to build a system on which he could base his poetry. There are, however, two important elements which we must bear in mind if we intend to grasp his concept of poetic evolution. The first of these elements is obviously the theory of the Mask or Daimon. Related to this is another fundamental image: the Tower. As we have already pointed out, both elements appear in the second Book of The Wanderings of Oisin but, curiously enough, they have never been associated with the symbols which appear in $A$ Vision. What do these interrelated concepts mean in Yeats's poetic theory? The Daimon is simply the image of the antiself, i.e. the mask which the poet must wear in order to achieve an equilibrium of subjective emotion and objective reality. By wearing the mask, the poet can fuse both the transcendental and the empirical halves of his split nature. That is to say, he can bring together in his poetry the private sphere of the self and the outer world which he had previously rejected. Only then can he reconcile himself with the image of the "other" and thus overcome the growing feeling of isolation of pure subjective poetry. However, this attempt to unify the two levels of the self can only be conceived of as a dramatic tension, i.e. as a type of struggle in which the poet tries to identify himself with his opposite: 
If we cannot imagine ourselves as different from what we are and assume the second self, we cannot impose a discipline upon ourselves, though we may accept one from others. Active virtue as distinguished from the passive acceptance of a current code is therefore theatrical, consciously dramatic, the wearing of a mask. It is the condition of arduous full life. (Autobiography 285)

I do not intend here-nor am I qualified-to give a full account of Yeats's complex theory of the mask. What I would like to emphasize however is the fact that from an ideological viewpoint, the Daimon arises as Yeats's representation of whatever is alien to the isolated nature of the poet. In other words, the Daimon is the Yeatsian image of the bourgeois category of the object. And it is clear that it is only by attempting to close the gap between subject and object-or following Yeats's terminology, self and antiself - that the poet can at least temporarily overcome this oppressive dichotomy and link his subjective discourse with the outer world. Unterecker summarizes this point as follows:

His problem, therefore, was to discover a technique by which the personal could somehow be objectified, be given the appearance of "personal" truth and yet retain the emotive force of privately felt belief. A partial solution was the theory of the Mask. (16)

If we accept this as a sound basis for the interpretation of a poem like The Wanderings of Oisin, many problems can be solved definitely. Thus, if the wearing of the mask-or the power to assume our opposite--is primarily seen as a dramatic tension, we should not be surprised that the poem translates this entire objectivity-oriented process into the image of a "never-ending battle" with the demon. A battle which is endless precisely because the demon, as the image of the "other," may incarnate all that is different from the self. For this reason, he constantly modifies his appearance throughout his battle with Oisin. The hero first lunges "at the smooth throat/Of a great eel" (21); later he smites "A fir-tree roaring/in its leafless top" and finally draws "the livid chop/Of a drowned dripping body to [his] breast" (22). Not surprisingly, this eternal battle with an ever-changing demon bears too many resemblances to Yeats's conception of poetry as "a re-birth as something not oneself, something which has no memory and is created in a moment and perpetually renewed" (Autobiography 306). Thus, by destroying any of the possible forms through which the demon may appear, Oisin is "perpetually" transforming himself into his opposite and it is only through this transformation that poetry is now created. ${ }^{5}$ Accordingly, Oisin-the changeless poetic self-must struggle with the demon-his antiself-partly because this eternal battle becomes the only means to free his poetry from the danger of subjectivism, and partly because the "subject-object" confrontation now reveals itself as the only possibility of enlarging the poet's knowledge and vision of reality.

There still remains the problem of elucidating the symbolic meaning of the "tower." We must remember that Oisin fights with the demon because he wants to rescue the "softeyed lady" who, tied with a "wave-rusted chain" to a couple of eagles, is imprisoned in it. In fact, the description of the tower is so charged with symbolic reverberations that it is difficult to understand the meaning of all the emblematic forms used in its depiction. I will merely point out some of the most significant motifs which are present in the episode of 
the lady's deliverance. First of all, Oisin and Niamh can only reach the top of the tower through "a countless flight/Of moonlit steps": “ . . we climbed the stair/And climbed so long, I thought the last steps were/Hung from the morning star ..." (18). Secondly, the entrance to the tower is flanked by two "dark statues," one of which seems to envision the history of man "since God made Time and Death and Sleep," whereas the other appears to control the infinite dimension of space. Which symbolic meaning does all this strange episode enact? According to C. M. Bowra, the tower stands for "the aspirations of the intellect" and those of the soul, whereas the staircase symbolizes "the intrincate process by which the self ascends" in order to achieve vision or a more profound perception of reality (212-13). If Bowra's interpretation is correct, this might mean that the lady represents Yeats's early symbolic embodiment of the "Creative Mind" or "Spirit," one of the four principles or faculties that the poet believed to control the world. Oisin's ascent to the tower is therefore the self's attempt to achieve the unison of his "Will" (Sense, Emotion) with an impersonal objective "Thought," a unity which can shake off the subjectivism of his early poetry and overcome the narrow vision of the Island of Dancing. The lady's rescue is then the image of the poet's achievement of a "Creative Mind" aware of the problems of the ever-changing external world and of the oppressive laws of Time and Space ("the dark statues" on both sides of the tower). In this sense, the lady's song which Oisin hears when he begins to go up the stairs is notew orthy. The lady can but sing of the battles of the world which Oisin has abandoned, and of the destiny of his people:

My brothers spring out of the their beds at morn,

A murmur like young partridge: with loud horn

They chase the noontide cheer;

And when the dew-drowned stars hang in the air

Look to long fishing-lines, or point and pare

An ashen hunting spear. (18)

And her sadness--the sadness of a wasted Creative Mind-is no other than the result of her long wait for the poet who could rescue her from the solitude of unfulfillment and capture her powers of insight in an unperishable work of art:

O sigh, O fluttering sigh, be kind to me;

Flutter along the froth lips of the sea ... And tell me that you found a man unbid, The saddest of all men. (18)

This is precisely Oisin's battle: to find a creative pattern which can endow his poetry with a perfect balance between the subjective and objective halves of his nature; a "Creative Mind" which can only be attained by disciplining the Self (Oisin, the Ego) and its antiself (the demon or the Other). In other words, Oisin's paradoxical conflict is nothing but the desperate struggle to produce a kind of poetry which remains timeless even though it crosses the borders of the outer world and is thereby defiled by the polluting social turmoil of Irish history. Finally, it is a poetry which has to maintain a difficult equilibrium 
between all that is subjectively eternal and all that is objectively transient. And it is precisely from the uniting of these opposites that Oisin's victory emerges.

(III) The Concept of Timeless or Visionary Poetry or the Island of Forgetfulness

"All art is dream"

W. B. Yeats

Yeats's contradictory attempts to provide his poetic imagination with an "objective" knowledge of the world and his constant efforts to reconcile his poetry with the previously rejected social reality soon revealed their inability to resolve many of the poet's conflicts. First of all, the "single geometrical conception" on which he based his psychological and historical theories, far from removing man's anxieties about his inevitable destiny-Time and Death-only served at most to postpone them: history was conceived of as cyclic rather than linear - the continuous turning of the Wheel-yet man still had to accept that his was inevitably a mortal fate. Secondly, his dislocated position within Irish society and his problematic relation to his audience have always been widely discussed critical questions. ${ }^{6}$ However hard Yeats tried to write poetry for his people, his poetic production was not always properly understood or as well received as he had expected it to be. Despite all his arduous efforts, he was still forced into the role of the isolated poet talking to an imaginary reader.

How is the final stage of the poet's evolution represented in the poem we are dealing with? A hundred years of continuous struggle on the second island can only lead Oisin to the pessimistic conclusion that all man's efforts to achieve his goals are useless in the long run and that nothing can be done to halt the passing of time: "Light is man's love and lighter is man's rage;/ His purpose drifts and dies"(24). The Islands of Dancing and Victories have proved to be "empty of all power" and when Oisin, tired of the long journey, asks his inseparable companion the fundamental question "And which of these/Is the Island of Content?," Niamh's answer-"None know"-at once reveals the futility of the hero's quest. The following step could be no other than search for the Island of Forgetfulness, i.e. to leave behind the vexing struggles of the objective world (or "to shake off the habits of time and place," as Yeats put it) and to return to the self. In other words, what Oisin aims to find is the lost tranquillity of his early subjectivity. What he finds instead is a different image of his identity inevitably enlarged by a more profound knowledge of the world but also deeply transformed by the weariness of passions.

These two features-weariness and a greater knowledge gained through experience-are symbolically enacted by the "monstruous slumbering folk" that Oisin finds asleep in the valley. ${ }^{7}$ That they have reached a deeper vision of reality can be perfectly seen in their inordinate size (they are giants) and in the bird-imagery by which they are depicted. Thus, "the tops of their ears" are covered with feathers and instead of hands they have "claws of birds." More interesting, perhaps, is the fact that their heads are full of owls building their nests. We have already pointed out the possible meanings of the bird-symbolism in Yeats's poetry: birds are a primary symbol of subjectivity but they are 
also an emblem of a more acute perception of reality. Obviously enough, the owl is the bird which symbolizes wisdom simply because it can see despite the darkness. It is no coincidence, then, that this is the kind of bird which the poet chooses to symbolically represent the degree of knowledge and vision of reality which the inhabitants of the island seem to have reached: "So long were they sleeping, the owls had builded their nests in their locks,/Filling the fibrous dimness with long generations of eyes" (26).

Yet there is still another unsolved question: why do the giants sleep? First-and this would be the easiest answer-because only by sleeping can they forget the battles they have fought and heal the wounds which the contact with the "Anima Mundi" produces:

I saw how those slumberers, grown weary, there camping in grasses deep,

Of wars with the wide world and pacing the shores of the wandering seas,

Laid hands on the bell-branch and swayed it, and fed of unhuman sleep. (26-27)

Second and perhaps more important, their sleep is symbolic of that which Yeats saw in the subconscious experience of dream, i.e. one of the most elevated forms of knowledge and the only means to discover the secrets and mysteries concealed in the universe. The dream thus becomes the introspective quest for the the self's real identity and for its true link with the-world; a kind of imaginary journey which definitely seems to overcome the obstacles of time and space. Yeats remarks in this sense:

The soul cannot have much knowledge till it has shaken off the habit of time and place... Yet even now we seem at moments to escape from time in what we call prevision, and from place when we see distant things in a dream and in concurrent dreams. (Per Amica Silentia Lunae 57)

The dream reveals the "Great Memory" of the world and permits the poet to return to the past or to anticipate the future. Exhausted by the positivist knowledge of reality which can only provide empirical definitions of the material objects, the poet is now forced to "invent a new process" whereby his subconscious mind can finally grasp the unfathomable meaning of many a symbol:

I had found that after evocation my sleep became at moments full of light and form, and all that I had failed to see while awake; and I elaborated a symbolism of natural objects that I might give myself dreams during sleep or rather visions ... by laying upon my pillow or beside my sleep certain flowers or leaves. Even to-day ... the exaltations and the messages that came to me from bits of hawthorn or some other plant seem, of all moments of my life, the happiest and the wisest. (Per Amica Silentia Lunae 49, emphasis added $)^{8}$

It is precisely this "new process" of discovering images by means of sleep that Oisin finds in the Island of Forgetfulness. The giants are not sleeping in a literal sense; what they are actually doing is exploring the hidden symbolic meaning of reality, i.e. finding a kind of revelation of all that lies behind the objective empirical form of matter. Like Yeats, they also sleep beside "certain flowers or leaves": during his sleep they do not cease to touch 
and sway "bell branches." Similarly, Oisin slumbers "in the roots of the grasses, the sorrels" whereas "square leaves of the ivy" watch over his dreams. Not surprisingly, the visionary revelation of the "light and form" of which Yeats spoke, also takes place in the island:

At times our slumber was lightened. When the sun was on silver or gold;

When brushed with the wings of the owls, in the dimness they love going by;

When a glow-worm was green on a grass-leaf, lured from his lair in the mould;

Half wakening, we lifted our eyelids, and gazed on the grass with a sigh.

(29 emphasis added)

Seen from this perspective, the symbolic connotations which can be associated with the sleeping giants are far more complex than those traditionally pointed out by critics. This island is not simply an image of physical rest after the arduous experiences and battles of the Island of Victories, and much less of the symbolic enactement of the final stage of man's life ("the old age," as Ellmann suggested). ${ }^{9}$ In my opinion, the Island of Forgetfulness epitomises the poet's last attempt to discover the timeless secrets and mysteries of the world, i.e., the final stage in the process of achieving a "unified reality which satisfies the whole being." In other words, the visionary poetry which was Yeats's ideal towards the end of his life.

\section{Notes}

1. All the quotations from The Wanderings of Oisin included hereafter have been taken from Yeats's Poems, ed. A. Norman Jeffares, 5-35. The number in brackets which accompanies each quotation of the poem indicates the number of the page of this edition.

2. Yeats spelled the word "Daimon" in his prose writings. In the poems, however, it is always spelled "demon."

3. There is a good deal of textual evidence that shows that Niamh can be seen as a new personification of the legendary myth of the White Goddess: (1) like Keats's Moneta or "La Belle Dame sans Mercy," she is a "pearl-pale high-born lady" who rides a horse; (2) she chooses Oisin as her companion because "she is dizzy with . . . the fame "of stories builded with his words"; (3) she is constantly connected with the moon: the Danaan land from which she comes is a place somewhere between the sea and the pale moon; (4) and finally one of her most distinctive features is the mysterious power of her "unhuman voice." See Robert Graves' The White Goddess (1961) for further information about the representation and symbolic features of the White Goddess in poetry.

4. Cf. Arthur Symons's first section ("The World as Ballet") of his essay Ballet, Pantomime and Poetic Drama. The quotation is from Frank Kermode Romantic Image 73-74.

5. Note that Oisin kills the demon in several of its forms with the sword of Manannan, the Irish sea-god. The symbolic connotations of the sword in Yeats's poetry have been widely discussed. For A. Barghava "the sword is, like a work of art, a symbol of order and imperishability. Yeats regarded it as an immortal art product." See Ashok Barghava, The Poetry of W. B. Yeats: Myth as Metaphor 146. 
6. See Terry Eagleton's brief but suggestive analysis of Yeats's "dislocated" ideological position within Irish society in his work Criticism and Ideology 151-54. For a deeper investigation into the question of Yeats's relation to his public, the work by C. K. Stead The New Poetic Yeats to Eliot can be consulted. More interesting, however, is David Ward's article "Yeats's Conflicts with his Audience, 1897-1917."

7. The Island of Forgetfulness might well represent the cyclic return to the process of gestation. The "naked and gleaming" giants sleep in a fetus-like position and the valley in which Oisin finds them - with its protective concave form and its dark humidity -is a clear symbolic motif of the maternal womb.

8. See also "The Symbolism of Poetry" in Essays and Introductions. Yeats states that "in the making and in the understanding of a work of art, and the more easily if it is full of patterns and symbols and music, we are lured to the threshold of sleep. .." (160).

9. There is no textual evidence that shows that the giants of the Island of Forgetfulness are old: they cannot operate as a symbol of man's old age. They are only white bird-like creatures, wearied by the battles of life.

\section{Works Cited}

Adams, Hazard. Blake and Yeats: The Contrary Vision. New York: Russell Russell, 1955.

Bachelard, Gaston. L'air et les songes: essai sur l'imagination du mouvement. Paris: Libraire José Corti, 1943.

Barghava, Ashok. The Poetry of W. B. Yeats: Myth as Metaphor. New Jersey: Humanities P, 1980. Bowra, C. M. The Heritage of Symbolism. London: Macmillan, 1943.

Eagleton, Terence. Criticism and Ideology. London: Verso, 1978.

Ellmann, Richard. The Identity of Yeats. London: Faber, 1954.

García Montero, Luis. Poesía, cuartel de invierno. Granada: Diputación Provincial de Granada, 1987.

Graves, Robert. The White Goddess: A Historical Grammar of Poetic Myth. London: Faber, 1961. Jeffares, Norman A. The Poetry of W. B. Yeats. London: Arnold, 1961.

Kermode, Frank. Romantic Image. London: Routledge and Kegan Paul, 1957.

Langbaum, Robert. The Mysteries of the Self: A Theme in Modern Literature. New York: Oxford UP, 1977.

Langbaum, Robert. The Poetry of Experience: The Dramatic Monologue in Modern Literary Tradition. London: Chatto and Windus, 1957.

Stead, C. K. The New Poetic: Yeats to Eliot. London: Hutchinson, 1964.

Unterecker, John. A Reader's Guide to W. B. Yeats. London: Thames and Hudson, 1959.

Ward, David. "Yeats's Conflicts with his Audience, 1897-1917." English Literary History 49 (1982): 143-63.

Wilson, Edmund. Axel's Castle: A Study of the Imaginative Literature of 1870-1930. 1930. London: Fontana, 1984.

Yeats, W. B. Poems. Ed. Norman A. Jeffares, London: Papermac-Macmillan, 1989. Letters. Ed. A. Wade, London: Hart Davies, 1954. "The Symbolism of Poetry." Essays and Introductions, London: Macmillan, 1961. The Autobiography of William Butler Yeats. 1935. New York: Macmillan, 1953.

Yeats, W. B. "Per Amica Silentia Lunae." A Vision and Related Writings. Ed. Norman A. Jeffares. London: Arena, 1990. 